\title{
PENGGUNAAN METODE UMMI DALAM RANGKA PENINGKATAN KEMAMPUAN MEMBACA AL-QUR'AN BAGI IBU RUMAH TANGGA
}

\author{
Annisa Fadhilah Liansyah ${ }^{1}$, N. Achadianingsih ${ }^{2}$ \\ 1,2, 3 Program Studi Pendidikan Masyarakat IKIP Siliwangi, Cimahi, Jawa Barat, Indonesia \\ ${ }^{1}$ annisafadhilahliansyah11@yahoo.com
}

Received: Agustus, 2020; Accepted: September, 2020

\begin{abstract}
Instilling motivation in adults, especially housewives in helping and improving reading skills in studying the Qur'an is not an easy thing to do, because housewives who are no longer productive in terms of age are also busy with managing their household, this in daily practice requires persistence, patience, exemplary and of course the provision of great motivation in learning by tutors. The Ummi method in this case is an innovative method of learning Al-Qur'an which is present according to the needs of the community, especially adults in order to improve the ability to read Al-Qur'an, especially for housewives. This research is a qualitative research with descriptive design. The results of the study obtained the following data: 1) Learning planning is arranged with the stages of socializing the Lembang qur'an house program, recruiting adult students, especially housewives, grouping students according to their level of ability to read al - qur'an, making schedules learning al - qur'an house qur'an lembang, compiling steps for learning home program qur'an lembang. 2) The implementation stage starts from the initial stage in the form of an opening which shows the existence of learning conditioning (learning climate) that supports the growth of adult learning motivation. 3) Evaluation on the improvement of reading the Al - Qur'an, the Ummi method for housewives is focused on adult learning motivation, the process of implementing the learning activities of the tutors, and the results so that the implementation of improving reading the Al - Qur'an Ummi method is still not optimal due to inhibiting factors that must be addressed.
\end{abstract}

Keywords: penilik, literacy, ICT

\begin{abstract}
Abstrak
Menanamkan motivasi pada orang dewasa khususnya ibu rumah tangga dalam membantu dan meningkatkan kemampuan membaca dalam mempelajari Al - Qur'an bukan hal yang mudah dilakukan, dikarenakan ibu - ibu rumah tangga yang dalam segi usianya sudah tidak produktif lagi pun kesibukan yang dilakukan dalam mengurus rumah tangganya, hal tersebut dalam praktek keseharian membutuhkan ketekunan, kesabaran, keteladanan dan tentunya pemberian motivasi yang besar dalam belajar oleh para tutor. Metode Ummi dalam hal ini merupakan sebuah metode inovasi pembelajaran $\mathrm{Al}$ - Qur'an yang hadir sesuai dengan kebutuhan masyarakat khususnya orang dewasa dalam rangka peningkatan kemampuan membaca Al - Qur' an khususnya bagi ibu rumah tangga. Penelitian ini adalah penelitian kualitatif dengan desan deskriptif. Hasil Penelitian diperoleh data sebagai berikut : 1) Perencanaan pembelajaran ditata dengan tahap - tahap melakukan sosialisasi program rumah qur'an lembang, merekrut peserta didik orang dewasa khususnya ibu rumah tangga, pengelompokan peserta didik sesuai tingkat kemampuan membaca al - qur'an,pembuatan jadwal pembelajaran al - qur'an rumah qur'an lembang, menyusun langkah - langkah pembelajaran program rumah qur'an lembang. 2) Tahap pelaksanaan dimulai dari tahap awal berupa pembukaan yang menunjukan adanya pengkondisian belajar (iklim pembelajaran) yang mendukung tumbuhnya motivasi belajar orang dewasa. 3) Evaluasi pada peningkatan membaca Al - Qur'an metode Ummi pada ibu rumah tangga ini difokuskan kepada motivasi belajar orang dewasa, proses pelaksanaan kegiatan pembelajaran para tutor, dan hasil sehingga pelaksanaan peningkatan membaca $\mathrm{Al}$ - Qur'an Metode Ummi masih belum bisa berjalan optimal dikarenakan adanya faktor - faktor penghambat yang harus di benahi.
\end{abstract}

Kata Kunci: Metode Ummi dan Metode Inovasi pembelajaran Al - Qur'an 
182 Liansyah\&Achadianingsih, Penggunaan Metode Ummi Dalam Rangka Peningkatan Kemampuan Membaca Al-Qur'an Bagi Ibu Rumah Tangga

How to Cite: Liansyah \& Achadianingsih. (2020). Penggunaan Metode Ummi Dalam Rangka Peningkatan Kemampuan Membaca Al-Qur'an Bagi Ibu Rumah Tangga. Comm-Edu (Community Education Journal) 3 (3), 181-187.

\section{PENDAHULUAN}

Al - Qur'an merupakan suatu pedoman dan petunjuk hidup bagi umat islam, yang didalamnya sudah tidak ada suatu keraguan lagi. Hal tersebut sesuai dengan Firman Allah dalam Qur'an Surah Al - Baqarah ayat 2, yang artinya "Kitab (Al - Qur' an) ini tidak ada keraguan padanya; petujuk bagi mereka yang bertakwa." . dari arti tersebut dapat terlihat jelas bahwa betapa pentingnya $\mathrm{Al}$ - Qur;an sebagai pedoman dan petunjuk hidup bagi umat Islam, maka dari itu masyarakat yang beragama Islam tentunya harus mampu membaca Al - Qur'an dengan benar sesuai dengan kaidah atau aturan membacanya.

Kebutuhan masyarakat terhadap pembelajaraan membaca Al - Qur'an yang baik dirasa semakin kini semakin banyak. Itu merupakan suatu hal yang patut kita syukuri, akan tetapi kebutuhan tersebut belum diimbangi dengan ketersediannya sumber daya manusia (SDM) pengajar $\mathrm{Al}$ - Qur'an yang memiliki kompetensi dan komitmen di bidang pembelajaran $\mathrm{Al}$ Qur'an yang memadai. Oleh karena itu Ummi Foundation ingin berkontribusi dengan semangat Fastabikhul Khoirot (berlomba-lomba dalam kebaikan) dalam memberi solusi terhadap problem kualitas pembelajaran $\mathrm{Al}$ - Qur'an bagi lembaga - lembaga majelis yang ada di lingkungan masyarakat saat ini melalui program standarisasi tutor $\mathrm{Al}$ - Qur' an atau program diklat tutor $\mathrm{Al}$ - Qur' an agar pembelajaran $\mathrm{Al}$ - Qur'an di masyarakat semakin berkualitas.

Pembelajaran Al - Qur'an yang baik membutuhkan sebuah system yang mampu menjamin mutu setiap warga belajar yang ingin belajar membaca Al - Qur'an agar cepat dan mudah membaca Al - Qur'an secara tartil. Dan sebagaimana halnya program pemebelajaran yang lainnya bahwa dalam pembelajaran Al - Qur'an juga membutuhkan pengembangan, baik secara konten, konteks maupun support system - nya.

Seperti yang tertera dalam Keputusan Bersama Menteri Dalam Negeri dan Menteri Agama RI nomor 128 tahun 1982/44 A 82, Th 1990 menyebutkan bahwa : Perlunya usaha meningkatkan kemampuan baca tulis $\mathrm{Al}$ - Qur'an bagi umat Islam dalam rangka peningkatan penghayatan dan pengamalan $\mathrm{Al}$ - Qur' an dalam kehidupan sehari - hari”.

Maka dari itu untuk meningkatkan penghayatan dan pengamalan $\mathrm{Al}$ - Qur' an dalam kehidupan sehari - hari, sangat perlu diadakan pembelajaran Al - Qur' an yang benar tidak hanya kepada lembaga - lembaga pendidikan formal saja tetapi juga sangat perlu dikembangkan kepada kelompok - kelompok kecil masyarakat tanpa memandang usia, contohnya kepada majelis pengajian orang dewasa yang di dalamnya terdiri dari ibu ibu usia pertengahan hingga usia lanjut.

Namun Pendidikan orang dewasa, masalahnya adalah lebih luas dari pada sekedar mengajarkan orang dewasa yang buta huruf untuk pandai membaca dan menulis. Batasan yang direkomendasikan UNESCO dapat diterjemahkan sebgai berikut : "Istilah Pendidikan Orang Dewasa berarti keseluruhan proses pendidikan yang diorganisasikan apapun isi, tingkatan dan metodenya, baik formal maupun tidak, yang melanjutkan maupun menggantikan pendidikan semula di sekolah, kolese dan universitas serta latihan kerja, yag membuat orang yang dianggap dewasa oleh masyarakat mengembangkan kemampuannya, memperkaya pengetahuannya, 
meningkatkan kualifikasi teknis atau profesionalnya, dan mengakibtkan perubahan pada sikap dan peilakunya dalam perspektif rangkap perkembangan pribadi secara utuh dan partisipasi dalam perkembangan sosial, ekonomi dan budaya yang seimbang dan bebas." (Lunandi,1984: 1; Sa'ud, 2008: 1) menyatakan bahwa, "Inovasi (Innovation) ialah suatu ide, barang, kejadian, metode yang dirasakan atau diamati sebagai suatu hal yang baru bagi seseorang atau sekelompok orang (masyarakat) baik itu berupa hasil invention maupun diskoveri. Inovasi diadakan untuk mencapai tujuan tertentu atau untuk memecahkan suatu masalah tertentu. ". Nyatanya walaupun sudah banyak metode pembelajaran Al - Qur'an di Indonesia yang berkembang baik melalui sekolah formal atau melalui TPQ atau lembagaQur' an lainnya namun masih saja banyak fenomena yang bermunculan yang snagat terlihat kepermukaan tentang masih banyaknya orang dewasa yang belum tepat dalam melantunkan Al - Qur'an, Fenomena terebut peneliti temukan di beberapa daerah bahkan disekita rumah peneliti di kota Lembang khususnya masih banyak kejadian seperti ketika pengajian ibu - ibu di dekat rumah peneliti yang selalu menggunakan microfon masjid sebagai alat untun melantunka beberapa surah dan sholawat, namun masih terdengar kurang fasih dan tidak tepat sesuai kaidah bacaan Al Qur'an dengan aturan yang sesuai dan lebih tepat. Maka dari itu sangat penting sekali memperlajari Al - Qur'an dengan menggunakan metode yang sudah berstandar.

Dalam mewujudkan hal diatas Ummi Foundation membangun sebuah system mutu pembelajaran Al- Qur'an dengan melakukan standarisasi input, proses, dan outputnya. Keseluruhan standarisasi tersebut terangkum dalam 7 (tujuh) program dasar Ummi, yang meliputi; tashih, tahsin, sertifikasi, coach, supervise, munaqasah, dan khataman, dengan beberapa keuntungan dari system tersebut pembelajaran $\mathrm{Al}$ - Qur' an akan menemenukan titik kemudahan, kecepatan serta ketepatan dalam belajar membaca $\mathrm{Al}$ - Qur' an melalui beberapa metode dan strategi pembelajaran yang modern agar mampu menyentuh kalangan orang dewasa agar senantiasa belajar membaca $\mathrm{Al}$ - Quran dengan mudah, menyenangkan dan menyentuh hati.

Peneliti tertarik mengambil objek penelitian di Rumah Qur'an Lembang (RQL) yang berada di kota Lembang,Jl. Kenanga 3 Nomor 77 Pangragajian - Desa Kayu Ambon, Kecamatan Lembang, Kabupaten Bandung Barat. Di Rumah Qur'an Lembang (RQL) ini terdapat banyak sekali siswa yang dalam kategori pemula orang dewasa bahkan lanjut usia khususnya kaum ibu - ibu yang belajar membaca Al - Qur'an. Mereka pun terlihat sangat antusias sekali dan bersemangat dalam mengikuti pemebelajaran membaca $\mathrm{Al}$ - Qur'an dengan menggunakan Metode Ummi.

Berdasarkan fenomena - fenomena diatas, maka peneliti tertarik untuk mengadakan penelitian di Rumah Qur'an Lembang dengan judul "Penggunaan Metode Ummi Dalam Rangka Peningkatan Kemampuan Membaca Al-Qur'an Bagi Ibu Rumah Tangga." (Studi Kasus kelompok Ummi Dewasa di Rumah Qur'an Lembang Desa Kayu Ambon Kecamatan Lembang Kabupaten Bandung Barat).

\section{LANDASAN TEORI}

\section{Konsep Metode UMMI}

Metode Ummi merupakan metode membaca al-Qur'an dengan menggunakan pendekatan bahasa ibu, yaitu caranya langsung dibaca tanpa dieja, mengulang-ulang kata atau kalimat dalam situasi dan kondisi yang berbeda-beda. (Mashuri dan Yusuf dalam Belajar mudah Membaca Al - Qur'an Remaja dan Dewasa. Tahun 2007; 4-5.) 
Ummi Foundation dalam Modul Sertifikasi Guru Al - Qur'an, sebagai berikut :

1. Metode Ummi

Metode Ummi didesain untuk mudah dipekajari siswa, mudah diajarkan bagi guru/tutor dan mudah diimplementasikan dalam pembelajaran di sekolah formal maupun lembaga non formal. Metode Ummi dilakasanakan melalui proses pembelajaran yang menarik dan menggunakan pendekatan yang menggembirakan sehingga menghapus kesan tertekan dan rasa takut dalam belajar Al - Qur'an.

Para guru atau tutor yang mengajarkan Metode Ummi tidak sekedar memberikan pembelajaran $\mathrm{Al}$ - Qur' an secara material teoritik tetapi juga menyampaikan substansi akhlaq - akhlaq Al Qur'an yang diimplementasikan dalam sikap - sikap pada saat proses belajar mengajar berlangsung.

Pendekatan yang digunakan dalam pembelajaran Al - Qur'an Metode Ummi adalah pendekatan bahasa ibu, dan pada hakikatnya pendekatan bahasa ibu itu ada 3 unsur :

a. Direct Methode ( Metode Langsung)

Yaitu langsung dibaca tanpa dieja ; diurai atau tidak banyak penjelasan. Dengan kata lain learning by doing, belajar dengan melakukan secara langsung.

b. Repeatation ( diulang - ulang )

Bacaan Al - Qur'an akan semakin keliatana keindahan, kekuatan, dan kemudahannya ketika kita mengulang - ulang ayat atau surat dalam Al - Qur'an. Begitu pula seorang ibu dalam mengajarkan bahasa kepada anaknya. Kekuatan, keindahan, dan kemudahannya dengan mengulang - ulang kata atau kalimat dalam situasi dan kondisi yang berbeda - beda.

c. Kasih Sayang yang Tulus

Kekuatan cinta, kasih sayang yang tulus, dan kesabaran seorang ibu dalam mendidik anak adalah kunci kesuksesannya. Demikian juga seorang guru yang mengajar Al - Qur'an jika ingin sukses hendaknya meneladani seorang ibu, agar guru juga dapat menyentuh hati siswa mereka.

\section{Kekuatan Metode UMMI}

Metode Ummi tidak hanya mengandalkan kekuatan buku yang digunakan anak dalam belajar $\mathrm{Al}$ - Qur'an tetapi lebih pada 3 kekuatan utama :

a. Metode yang bermutu (Buku Belajar Membaca Al - Qur'an metode ummi)

Terdiri dari buku Pra TK, Jilid 1 - 6 Buku ummi Remaja/Dewasa, Ghorib Al - Qur'an, Tajwid Dasar beserta alat peraga dan metodologi pembelajaran.

b. Guru yang Bermutu

Semua guru yang mengajar Al - Qur'an Metode Ummi diwajibkan minimal melalui tiga tahapan, yaitu tashih, tahsin, dan sertifikasi Guru Al - Qur'an.

3. System Berbasis Mutu

System berbasis mutu di Metode Ummi dikenal 10 pilar system mutu. Untuk mencapai hasil yang berkualitas semua pengguna Metode Ummi dipastikan menerapkan 10 pilar system mutu ummi. Antara pilar satu dengan yang lain adalah rangkaian yang tidak dapat dipisahkan dalam implementasinya. 


\section{Tahapan Pembelajaran Metode UMMI}

Tahapan - tahapan pembelajaran Al - Qur'an Metode Ummi merupakan ini harus dijalankan secara berurutan sesuai dengan hierarkinya. Tahapan - tahapan pembelajaran Al - Qur'an Metode Ummi dijabarkan sebagai berikut :

1. Pembukaan

Pembukaan adalah kegiatan pengkondisian para siswa untuk siap belajar, dilanjutkan dengan salam pembuka dan membaca do'a pembuka belajar Al - Qur'an bersama - sama.

2. Apersepsi

Apersepsi adalah mengulang kembali materi yang telah diajarkan sebelumnya untuk dapat dikaitkan dengan materi yang akan diajarkan pada hari ini.

3. Penanaman Konsep

Penanaman Konsep adalah proses menjelaskan materi/pokok bahasan yang akan diajarkan pada hari ini.

4. Pemahaman

Pemahaman adalah memahamkan kepada anak terhadap konsep yang telah diajarkan dengan cara melatih anak untuk membaca contoh - contoh yang tertulis dibawah pokok bahasan.

5. Keterampilan/Latihan

Keterampilan atau latihan adalah melancarkan bacaan dengan cara mengulang - ulang contoh atau latihan yang ada pada halaman pokok bahasan dan halaman latihan.

6. Evaluasi

Evaluasi adalah pengamatan sekaligus penilaian melalui buku prestasi terhadap kemampuan dan kualitas bacaan anak satu persatu.

7. Penutup

Penutup adalah pengkondisian anak untuk tetap tertib kemudian membaca do'a penutup dan diakhiri dengan salam penutup dari Ustadz atau Ustadzah.

\section{Metode UMMI Sebagai Inovasi Pembelajaran Orang Dewasa}

Menurut Sa'ud dalam Inovasi Pendidikan (2008: 3) :

"Inovasi (innovation) ialah suatu ide, barang, kejadian, metode yang dirasakan atau diamati sebagai suatu hal yang baru bagi seseorang atau sekelompok orang (masyarakat), baik itu berupa hasil invention (penemuan sesuatu yang benar- benar baru) maupun discovery (penemuan sesuatu yang sebenarnya benda atau hal yang ditemukan itu sudah ada, tetapi belum diketahui orang), sebagai tujuan untuk memecahkan suatu masalah tertentu".

Dengan bertambahnya jumlah penduduk yang sangat cepat dan sekaligus bertambahnya keinginan masyarakat untuk mendapatkan pembelajaran seusai ketersediaan sarana pendidikan yang memadai maka Metode Ummi merupakan suatu alternative yang sangat memadai untuk keberlangsungan proses pembelajaran $\mathrm{Al}$ - Qur'an dalam menggunakan Metode Ummi.

Innovasi dalam tumbuhnya berbagai metode - metode membaca Al-Qur'an kini sangat marak untuk memenuhi kebutuhan masyarakat dengan berkembangnya ilmu pengetahuan yang modern menghendaki dasar dasar pendidikan yang kokoh dan penguasaan kemampuan terus menerus, dan dengan demikian menuntut pendidikan yang lebih lama sesuai dengan konsep pendidikan seumur hidup (life long education). 
Metode Ummi merupakan suatu metode baru dalam strategi pembelajaran Al - Qur'an di kalangan masyarakat umum. Metode tersebut merupakan suatu bentuk inovasi untuk pembaharuan alternatif dalam belajar membaca $\mathrm{Al}$ - Qur'an, agar masyarakat mendapatkan pembelajaran yang mudah dan menyenangkan, khususnya bagi kalangan orang dewasa yaitu ibu-ibu rumah tangga yang sudah memasuki kepala tiga biasanya sangat sulit untuk memahami suatu konsep atau pembelajaran dalam membaca Al - Qur'an.

\section{METODE}

Penelitian ini di laksanakan di Lembaga RQL (Rumah Qur'an Lembang) yang terletak di Jalan Kenanga 3 Nomor 77 Pangragajian Desa Kayu Ambon Kecamatan Lembang Kabupaten Bandung Barat. Lembaga RQL (Rumah Qur'an Lembang ) merupakan sebuah tempat Tahsin yaitu untuk mempelajari perbaikan bacaan $\mathrm{Al}$ - Qur'an dan Tahfidz yaitu hafalan $\mathrm{Al}$ - Qur'an dengan baik dan benar (Tartil). Dalam sebuah proses pembelajarannya di Rumah Qur'an Lembang menggunakan Metode UMMI sebagai salah satu metode membaca Al - Qur' an yang dipilih karena lebih mudah untuk dipelajarinya terutama untuk golongan orang dewasa salah satunya yaitu ibu rumah tangga.

Pada Penelitian Kualitatif subjek penelitian sebagai "Human Instrument" atau manusia informan maupun yang mencari data dan Instrumen utama penelitian kualitatif adalah peneliti itu sendiri sebagai ujung tombak pengumpulan data.

Menetukan subjek peneltian sangatlah penting untuk dijadikan sasaran utama penelitian agar tujuan penelitian tercapai. Menurut Suharsimi Arikunto $(1990 ; 116)$ subjek penelitian merupakan pemberian batasan subjek penelitian sebagai benda, hal atau tempat data untuk variable penelitian melekat, dan yang dipermasalahkan.

Data dalam penelitian ini menggali dari beberapa sumber data utama yang diambil melalui wawancara dan observasi yaitu Direktur RQL (Rumah Qur'an Lembang), Ustadz dan ustadzah tutor di Rumah Qur'an lembang, dan Peserta didik (dewasa) yaitu kelompok UMMI Dewasa (ibu rumah tangga) di Rumah Qur'an Lembang. Adapun subjek dari sumber data tambahan yaitu berupa Modul Sertifikasi Guru Al - Qur' an Metode UMMI, foto - foto, dan dokumen dokumen alat peraga bacaan yang berhubungan dengan pembelajaran membaca $\mathrm{Al}$ - Qur'an melalui Metode Ummi. Berikut data subjek penelitian :

Tabel 1. Subjek Penelitian

\begin{tabular}{|c|l|}
\hline No. & \multicolumn{1}{|c|}{ Subjek Penelitian } \\
\hline 1. & Bapak Wawan Budiman,S.Pd : Direktur RQL (Rumah Qur'an Lembang) \\
\hline 2. & $\begin{array}{l}\text { Ustadz dan ustadzah tutor di Rumah Qur'an lembang: } \\
\text { Ibu Iis Aisyah (Ustadzah / tutor kelompok Ummi Dewasa) }\end{array}$ \\
\hline 3. & $\begin{array}{l}\text { Peserta didik (dewasa) yaitu kelompok Ummi Dewasa (ibu rumah tangga) } \\
\text { di Rumah Qur'an Lembang }\end{array}$ \\
\hline
\end{tabular}

\section{HASIL DAN PEMBAHASAN}

\section{Hasil}

Berdasarkan hasil observasi penelitian di lapangan, jika dilihat dari konsep - konsep ukuran teoritis berkenaan dengan teori metoda Pendidikan Orang Dewasa (POD) yaitu bahwa 
pemilihan metoda hendaknya ditentukan oleh tujuan pendidikan (Lunandi, 1984 : 25). Pada garis besarnya dibagi menjadi dua jenis yaitu Pertama, proses belajar yang dirancang untuk membantu orang menata pengalaman masa lampau yang dimilikinya dengan cara baru. Kedua, proses belajar yang dirancang untuk memberikan pengetahuan baru, keterampilan baru, yakni mendorong individu meraih lebih jauh dari pada apa yang diketahuinya (Warren dalam Lunandi, 1984:25). Hal tersebut telah dilaksanakan oleh Lembaga Rumah Qur'an Lembang dengan konsep membaca Al - Qur'an dengan Metode Ummi yaitu menggunakan bahasa ibu, yaitu caranya langsung dibaca (direct method) tanpa dieja, mengulang - ulang (repetation) kata atau kalimat dalam situasi dan kondisi yang berbeda - beda (Manshuri dan Yusuf, hal 4-5).

Dilihat dari perkembangan tersebut animo masyarakat terhadap keinginan mempelajari metode membaca Al - Qur'an melalui Metode Ummi, sangat mepengaruhi terhadap kesadaran masyarakat untuk mempelajari Al - Qur'an. Dibawah ini ada beberapa data tentang peningkatan perioderisasi dan atau peminatan terhadap pembelajaran Al - Qur' an di Lembaga tersebut :

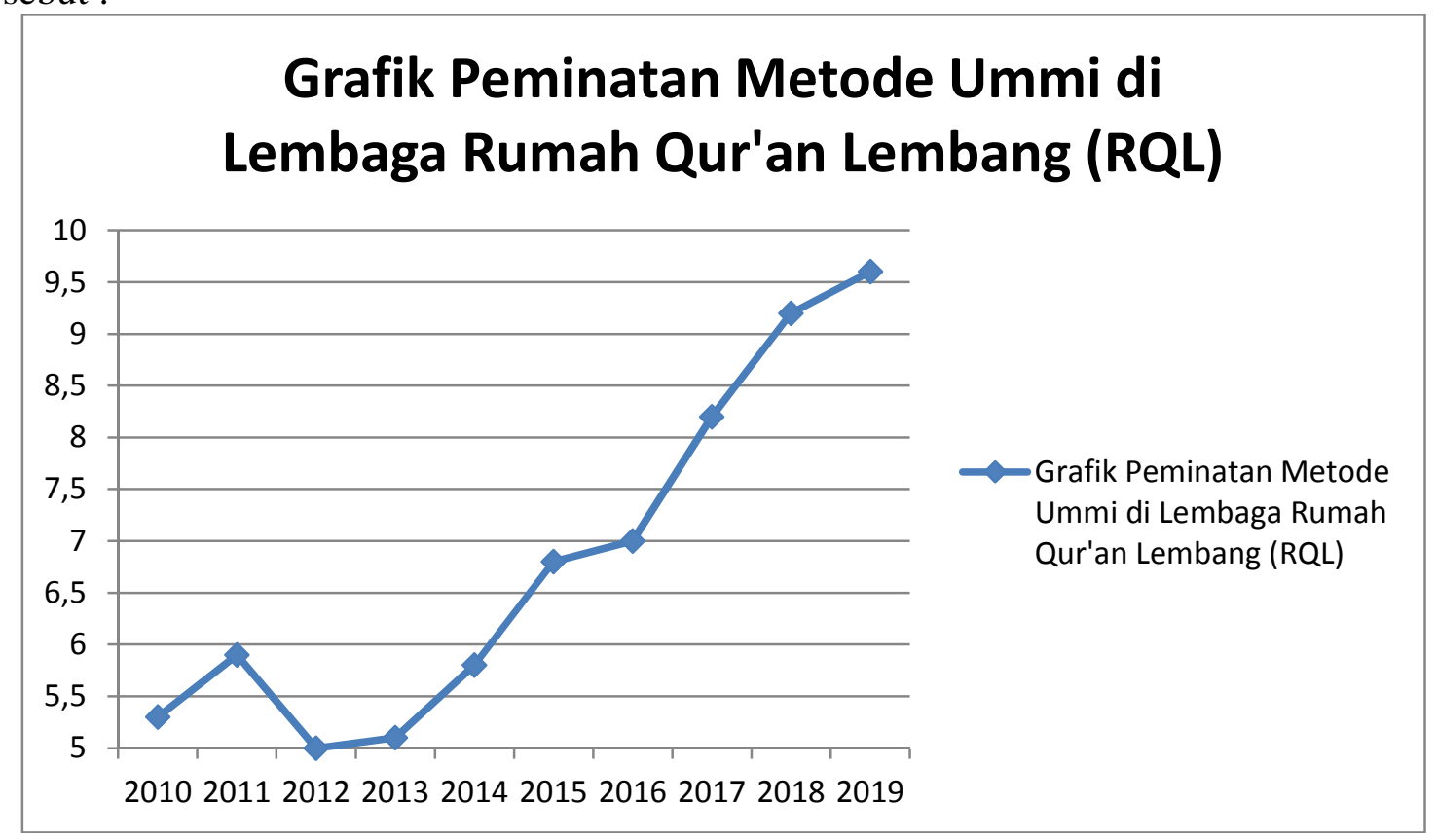

Gambar 1. Grafik Peminatan Metode Umi di Lembaga RQL

Sumber: Data diolah penulis berdasarkan data anggota member RQL per tahun.

Dari grafik diatas menunjukkan perkembangan peminatan pembelajaran orang dewasa (ibu rumah tangga) di Lembaga Rumah Qur'an Lembang mengalami peningkatan yang signifikan dari tahun 2014 hingga tahun 2019, pada tahun 2012 mengalami penurunan grafis dikarenakan adanya peralihan penyesuaian dari metode campuran yang didalamnya hanya $30 \%$ metode Ummi hingga memakai metode Ummi secara keseluruhan di tahun 2014.

Berdasarkan analisis penulis didapatkan suatu konsep Arief dalam Sudjana (2013 : 17) menggolongkan program pendidikan luar sekolah atas dasar sasaran, jenis program, dan lembaga penyelenggara. Atas dasar sasaran, program pendidikan luar sekolah dapat diklasifikasikan menurut karakteristik calon peserta didik (warga belajar) seperti latar belakang pendidikan, tingkatan usia, jenis kelamin, lingkungan tempat tinggal, dan latar belakang kelainan sosial. Hal tersebut sangat berkaitan dengan data dari hasil observasi dilapangan menghasilkan data dalam penggolongan program pembelajaran $\mathrm{Al}$ - Qur'an yang dijalankan oleh Lembaga Rumah Qur'an Lembang diklasifikasikan menurut kemampuannya dalam 
188 Liansyah\&Achadianingsih, Penggunaan Metode Ummi Dalam Rangka Peningkatan Kemampuan Membaca Al-Qur'an Bagi Ibu Rumah Tangga

membaca $\mathrm{Al}$ - Qur'an, menurut latar belakang pendidikan, usia, dan jenis kelamin. Berikut data yang dihasilkan :

Tabel 2. Klasifikasi Jilid Ummi berdasarkan Kelas dan Kemampuan Membaca

\begin{tabular}{|c|c|c|c|c|}
\hline No & Jilid Ummi & Materi & $\begin{array}{l}\text { Klasifikasi } \\
\text { Jilid Ummi } \\
\text { Dewasa }\end{array}$ & Kelas \\
\hline 1 & Jilid 1 & $\begin{array}{ll} & \text { Pengenalan huruf hijaiyah } \\
\text { berharakat fathah. } \\
\text { - } \quad \text { Huruf hijaiyah tunggal }\end{array}$ & \multirow{2}{*}{$\begin{array}{c}\text { Ummi Jilid } \\
1\end{array}$} & \multirow{6}{*}{ KELAS - 1} \\
\hline 2 & Jilid 2 & $\begin{array}{ll}\text { - } & \text { Pengenalan huruf hijaiyah } \\
\text { selain berharakat fathah. } \\
\text { - } \quad \text { Huruf sambung }\end{array}$ & & \\
\hline 3 & Jilid 3 & $\begin{array}{l}\text { - Pengenalan konsep panjang } \\
\text { dan pendek bacaan } 1 \\
\text { ayunan. } \\
\text { - Pengenalan konsep panjang } \\
\text { dan pendek bacaan } 2 \\
\text { ayunan. }\end{array}$ & \multirow[t]{2}{*}{$\begin{array}{c}\text { Ummi Jilid } \\
2\end{array}$} & \\
\hline 4 & Jilid 4 & 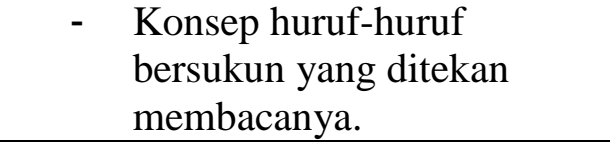 & & \\
\hline 5 & Jilid 5 & $\begin{array}{ll}\text { - } & \text { Pengenalan tanda waqaf } \\
\text { - } & \text { Konsep bacaan dengung. } \\
\text { - } & \text { Konsep pembacaan lafadz } \\
& \text { Allah. } \\
\text { - } & \text { Pengemahaman pembacaan } \\
& \text { Fawatihussuar. }\end{array}$ & \multirow[b]{2}{*}{$\begin{array}{c}\text { Ummi Jilid } \\
3\end{array}$} & \\
\hline 6 & Jilid 6 & $\begin{array}{l}\text { Konsep huruf bersukun } \\
\text { yang harus dipantulkan } \\
\text { membacanya } \\
\text { - } \quad \text { Konsep bacaan tidak } \\
\text { dengung } \\
\text { - } \quad \text { Waqaf ibtida } \\
\text { - } \quad \text { Bacaan panjang } 3 \text { ayunan. }\end{array}$ & & \\
\hline 7 & Jilid Ghorib & $\begin{array}{l}\text { Pengenalan ayat-ayat Ghoribah } \\
\text { (ayat - ayat asing) }\end{array}$ & \multirow{2}{*}{$\begin{array}{l}\text { Ummi Jilid } \\
\text { Tadarus }\end{array}$} & KELAS - 2 \\
\hline 8 & Jilid Tajwid & Membahas hukum - hokum tajwid. & & KELAS - 3 \\
\hline
\end{tabular}

Sumber : Data diolah penulis dari hasil observasi.

Berdasarkan data diatas peneliti mendapatkan perbedaan klasifikasi jilid maupun buku pegangan peserta didik antara peserta didik usia Remaja dan peserta didik Usia Dewasa, dilihat dari pengelompokkan ternyata buku jilid yang menjadi pegangan peserta didik orang dewasa hanya terbagi menjadi 3 buku jilid Ummi yang didalamnya sudah terangkum capaian - capaian materi secara tertata, perbedaanya terlihat pada halaman buku yang lebih dirangkum sesuai kebutuhan peserta didik orang dewasa sehingga hanya menjadi 3 jilid saja. 


\section{Pembahasan}

Dari data Gambar 1, diambil dari dua kelompok Ummi Dewasa, didapatkan $52 \%$ Ibu Rumah tangga dan $47 \%$ Wanita Karir yang mengikuti program mengaji melalui Metode Ummi di Rumah Qur'an Lembang. Maka dari itu hal tersebut membuktikan bahwa Lembaga Rumah Qur'an Lembang dapat mewujudkan masyarakat yang gemar membaca yang merupakan aalah satu sasaran perubahan yang ingin dicapai oleh pendidikan luar sekolah dalam pembangunan masyarakat adalah tumbuhnya masyarakat gemar belajar (learning society)). Masyarakat gemar belajar mengandung makna perubahan masyarkat dari situasi kehidupan semu, yang disebut masyarakat dalam keadaan mimpi (dreaming society) atau menghayal, kearah masyarakat berencana (planning society) (Sudjana, $2013: 271$ ).

Dan juga dilihat dari klasifikasi Usia yang didapat dari data tersebut membuktikan bahwa Lembaga Rumah Qur'an Lembang merupakan salah satu wadah pembelajaran pendidikan sepanjang hayat (life long education), merupakan pendidikan untuk pembangunan, pada dasarnya wajar dan alamiah dalam kehidupan umat manusia. kenyataan ini memberikan petunjuk mengenai pentingnya belajar sepanjang hayat (life long learning) di dalam kehidupan manusia untuk memenuhi kebutuhan belajar dan kebutuhan pendidikan terus tumbuh dan berkembang sepanjang alur kehidupan manusia. (Sudjana, 2013 : 217). Dalam aritian program yang diselenggarakan oleh Lembaga Rumah Qur'an Lembang itu tidak dibatasi oleh syarat usia maupun kemampuan untuk mempelajari $\mathrm{Al}$ - Qur' an, hal tersebut merupakan peningkatan membaca Al - Qur' an bagi Ibu rumah tangga yang mana seorang ibu rumah tangga merupakan orang dewasa yang ada di Rumah Qur'an Lembag untuk memenuhi kebutuhan belajar agar terus berkembang sepanjang alur kehidupan manusia, dikarenakan membaca Al - Qur' an itu bagi seorang muslim diwajibkan untuk bisa membaca, karena seorang muslim akan selalu berpedoman kepada $\mathrm{Al}$ - Qur' an sepanjang hayatnya.

Adapun didapatkan dari hasil observasi peneliti ketika mengamati kegiatan belajar mengajar didapatkan kunci keberhasilan dilihat dari 7 tahapan pembelajaran metode Ummi yang didalamnya terdiri tahap pembukaan, apersepsi, penanaman konsep, pemahaman konsep, latihan keterampilan dan penutup. serta di kuat dengan 10 pilar system mutu Ummi yang didalamnya terdapat Goodwill Management, Sertifikasi guru, tahapan yang baik dan benar, target jelas dan terukur, Mastery learning yang konsisten, waktu memadai, quality control yang intersif, quality control internal, quality control eksternal, rasio guru dan peserta didik proposional, progress report setiap peserta didik, dan koordinator yang handal.

Standarisasi diatas yang telah ditentukan oleh metode Ummi itu menjadi suatu nilai tolak ukur keberhasilan pertumbuhan dan perkembangan peminatan yang mampu juga meningkatkan mutu pembelajaran $\mathrm{Al}$ - Qur'an. Keberhasilan metode tersebut berkenaan dengan teori Inovasi pembelajaran orang dewasa.

Menurut Sa'ud dalam Inovasi Pendidikan,(2008 : 3) "Inovasi (innovation) ialah suatu ide, barang, kejadian, metode yang dirasakan atau diamati sebagai suatu hal yang baru bagi seseorang atau sekelompok orang (masyarakat), baik itu berupa hasil invention (penemuan sesuatu yang benar- benar baru) maupun discovery (penemuan sesuatu yang sebenarnya benda atau hal yang ditemukan itu sudah ada, tetapi belum diketahui orang), sebagai tujuan untuk memecahkan suatu masalah tertentu." Innovasi dalam tumbuhnya berbagai metode - metode membaca Al-Qur'an kini sangat marak untuk memenuhi kebutuhan masyarakat dengan berkembangnya ilmu pengetahuan yang modern menghendaki dasar dasar pendidikan yang kokoh dan penguasaan kemampuan terus - menerus, dan dengan demikian menuntut 
pendidikan yang lebih lama sesuai dengan konsep pendidikan seumur hidup ( life long education). Metode Ummi merupakan suatu metode baru dalam strategi pembelajaran $\mathrm{Al}-$ Qur'an di kalangan masyarakat umum. Metode tersebut merupakan suatu bentuk inovasi untuk pembaharuan alternatif dalam belajar membaca Al - Qur'an, agar masyarakat mendapatkan pembelajaran yang mudah dan menyenangkan, khususnya bagi kalangan orang dewasa yaitu ibu-ibu rumah tangga yang sudah memasuki kepala tiga biasanya sangat sulit untuk memahami suatu konsep atau pembelajaran dalam membaca Al - Qur'an.

Hal - hal tersebut yang mendominasikan tentang teknis untuk menunjang dan menguatkan praktek pembiasaan dalam pembelajaran metode Ummi, hal tersebut juga selaras dengan salah satu prinsip pembangunan masyarakat yaitu prinsip keterpaduan, bahwa program atau kegiatan pembangunan masyarakat disusun oleh, bersama, dalam dan untuk masyarakat atas dasar kebutuhan bersama dalam berbagai aspek kehidupan (Sudjana, 2013 : 266).

\section{KESIMPULAN}

Berdasarkan hasil penelitian yang dipaparkan dapat disimpulkan bahwa, masalah yang dirumuskan sebagaimana disebut dalam bab satu yaitu apakah benar metode Ummi dapat memberikan sumbangan terhadap peningkatan pengetahuan, pemahaman dan keterampilan membaca Al - Qur'an bagi Ibu Rumah Tangga yang berada di Lembaga Rumah Qur'an Lembang (RQL) di pandang sebagai metode Ummi yang cukup efektif menjadikan para peserta didik paham dalam membaca $\mathrm{Al}$ - Qur'an secara tartil, hal ini dibuktikan sebagai berikut :

1. Tahap Perencanaan Pembelajaran Al - Qur' an Metode Ummi di RQL

Perencanaan pembelajaran ditata dengan tahap - tahap melakukan sosialisasi program rumah qur' an lembang, merekrut peserta didik orang dewasa khususnya ibu rumah tangga, pengelompokan peserta didik sesuai tingkat kemampuan membaca al - qur'an,pembuatan jadwal pembelajaran al - qur'an rumah qur'an lembang, menyusun langkah - langkah pembelajaran program rumah qur'an lembang, terdiri dari pembuatan silabus, lembar penilaian, buku prestasi, dan penyelenggaraan program rumah qur'an lembang. Hal ini menghasilkan program pembelajaran yang relative cocok dengan kebutuhan warga belajar berupa buku prestasi, jurnal harian, penilaian harian dan buku jilid Ummi.

2. Tahap Pelaksanaan Pembelajaran Al - Qur'an Metode Ummi RQL

Dalam tahap awal berupa pembukaan yang menunjukan adanya pengkondisian belajar (iklim pembelajaran) yang mendukung tumbuhnya motivasi belajar orang dewasa, hal ini tutor dipandang sedikit banyak memahami konsep antara andragogi, dalam tahap isi relative terdapat adanya pembelajaran yang interaktif antara guru dan peserta didik dalam nuansa andragogi artinya adanya partisipasi dan kepedulian serta motivasi belajar peserta didik yang mendukung hasil pembelajaran.

3. Tahap Hasil Pembelajaran Al - Qur'an Metode Ummi RQL

Pada umumnya ibu rumah tangga mengetahui dan memahami makhorijul huruf dan dalam batasan batasan tertentu \pm didapatkan $52 \%$ Ibu Rumah tangga dan 47\% Wanita Karir yang mengikuti program mengaji melalui Metode Ummi di Rumah Qur'an Lembang. Dari keempat sample peserta didik bahwa tingkat pendidikan, faktor Usia, dan kesibukan menjadi ibu rumah tangga dapat memperangaruhi kualitas membaca Al - Qur'an dan kecepatan daya serap dalam memahami konsep konsep metode Ummi.

4. Faktor pendukung dan Penghambat dalam membaca Al Qur'an bagi Orang Dewasa Khususnya Ibu Rumah Tangga

Keberhasilan pembelajaran berupa adanya kesungguhan tutornya yang interaktif dan dapat menciptakan iklim atau suasana yag menyenangkan, ketekunan dalam proses pembelajaran serta kesabaran cukup mendukung terjadinya pembelajaran yang interaktif dan 
menyenangkan, sdedangkan daya dukung dari peserta didik yang mempunyai motivasi yang tinggi pun dapat meningkatkan semangat belajar.

5. Faktor penghambat adalah belum semua tutor yang sudah tersertifikasi metode Ummi sehingga hal tersebut dapat menentukan hasil yang di rasakan oleh peserta didik. Jika dari peserta didik faktor penghambatnya terdapat pada latar belakang usia yang sangat variatif dengan pendidikan yang dimilikinya relative rendah pun dalam aspek aktivitasnya dalam kesibukan mengurus rumah tangga dan keluarganya juga dapat memperhambat proses pembelajaran.

\section{DAFTAR PUSTAKA}

Arikunto, Suharsimi, 1990. Manajemen Penelitian. Jakarta : Rineka Cipta.

Bungin, Burhan. 2003. Analisis Data Penelitian Kualitatif ; Pemahaman Filosofis dan Metodologis kearah Penguasaan Model Aplikasi, Jakarta : PT. Raja Grafindo Persada.

Bungin, Burhan. 2007. Penelitian Kualitatif. Jakarta : Prenada Putra Grafika.

Hasan, Iqbal. 2002. Pokok - Pokok Materi Metode Penelitian dan Aplikasinya.Bogor : Ghalia Indonesia.

Lunandi, 1984. Pendidikan Orang Dewasa. Jakarta : PT Gramedia, Anggota IKAPI.

Mappiare, Andi. 1983. Psikologi Orang Dewasa. Surabaya : Usaha Nasional.

Mashuri dan Yusuf, 2007. Belajar Mudah Membaca Al - Qur'an Remaja \& Dewasa. Surabaya : Lembaga Ummi Foundation.

Miles dan Huberman. 1992. Analisis Data Kualitatif. Jakarta : Universitas Indonesia Press

Modul Sertifikasi Guru Al - Qur' an Metode Ummi pada tanggal 22-25 Juni 2016, Surabaya : Ummi Foundation.

Muchlas, Imam. 2004. Metode Penafsiran Al - Qur'an. Malang : UMM Press.

Nasution. 2003. Metode Penelitian Narulistik Kualitatif. Bandung : Tarsito.

Nazir,Moh, 1999. Metode Penelitian. Cet. IV. Jakarta : Ghalia Indonesia.

Poerwandarminta, 2011. Kamus Umum Bahasa Indonesia.Jakarta : Balai Pustaka.

Sa’ud, Syaifudin U. 2008. Inovasi Pendidikan. Bandung : Alfabeta.

Santori, Djam'an dan Komariah, Aan. 2009. Metodologi Penelitian Kualitatif. Bandung : Alfabeta.

Sudjana, 2013. Pendidikan Luar Sekolah. Bandung : Falah Production.

Sugiono. 2015. Memahami Penelitian Kualitatif. Bandung : Alfabeta.

Sugiyono, 2012. Metode Penelitian Kuantitatif Dan Kuaitatif Dan R\&D. Bandung : Alfabeta. 